\title{
ASPECTOS GERAIS DO DIREITO CONTRATUAL POLONÊS *
}

\author{
Prof. WENCESLAW JOSEPH WAGNER
}

(Da Faculdade de Direito da Universidade

de Indiana, EE.UU.)

A reviravolta política imposta aos países da Europa Central, depois da Segunda Guerra Mundial, trouxe naturalmente importantes mudanças em seus sistemas legais. No que diz respeito à esfera do Direito Público, não poderia ter sido diferente. Porém, qual foi o impacto dos desenvolvimentos estruturais dêsses Estados nos respectivos direitos privados, e, particularmente, no direito contratual? (')

Pode ser observado prontamente que a área de assuntos, na qual os indivíduos podem contratar, é muito mais restrita nesses países do que nos sistemas iurídicos tradicionais. Os assim chamados Estados Socialistas, que estão "em caminho para o comunismo", introduziram, como uma das primeiras reformas de suas estruturas econômicas, o princípio da propriedade estatal da maioria dos meios de produção e das emprêsas econômicas. $\left({ }^{2}\right)$ A vida industrial e comercial do país, assim como as relações entre as emprêsas estatais ou "organizações socialistas", é baseada na planificação econômica. $\left({ }^{3}\right)$ Em tal situação, pouco resta para relações comerciais de importância entre pessoas naturais ou jurídicas de Direito Privado. $\left({ }^{4}\right)$

* (Tradução do inglês pelo Auxiliar de Ensino SANSÃo JOSÉ LOUREIRO. Conferência pronunciada na Faculdade de Direito da Universidade Federal do Paraná.)

(O autor expressa sua gratidão ao Professor RUDOLF B. SCHLESINGER da Faculdade de Di reito da Universidade de Cornell, por suas valiosas sugestões sôbre o esbôço dêste estudo.)

1. Uma parte dêste estudo é baseada na introdução ao Direito Contratual polonês, preparada pelo autor para a sessão do Outono de 1961 do Projeto de Princípios Gerais da Fa. culdade de Direito de Cornell, e, publicada, com algumas modificaçōes no 11 Am. J. Comp. L. 348 (1962). O vocábulo "socialista" é usado neste artigo alternativamente com a expressão "comunista", e diz respeito aos países de economia planificada.

2. Os mais importantes setores da economia da Polônia foram nacionalizados pela lei de 3 de janeiro de 1946, Dz. U. de 5 de fevereiro de 1946, n.0 4, poz. 17, com correções.

3. A planificação econômica foi introduzida pelo Decreto de $1.0^{\circ}$ de outubro de $1947, \mathrm{Dz}$. U. n. 64, poz. 374 (1947); e o artigo 3.0 da Constituição de 1952 dispôs que a República "organizará uma economia planificada à base de emprêsas de propriedade social". Para alguns problemas de tal sistema, ver, por exemplo, POUNDS e SPULBER, Eds., Recursos e Planejamento na Europa Oriental (1957).

4. Na Polônia, desde 1948, a indústria foi nacionalizada, em $94 \%$. SZWEICER, Les Nationalisations en Pologne, em 14 Travaux et Recherches de I'Institut de Droit Comparé de I'Université de Paris, Les Nationalisations en France et à l'Étranger (1958) 213, 241. 
Apesar de todos os países comunistas terem inspiração ideológica comum, e de o sistema econômico da União Soviética exercer forte influência em todos os outros, não há um padrão uniforme em suas estruturas econômicas. Na verdade, as diferenças são pronunciadas. A situação na Polônia e na lugoslávia é mais semelhante à dos sistemas econômicos tradicionais, do que de outros Estados comunistas. Assim, em contrário a muitos outros países comunistas, as terras destinadas a uso agrícola ou pecuário, na Polônia, permaneceram, de modo geral, em mãos de particulares (embora as fazendas maiores tenham desaparecido), sendo deixada alguma liberdade aos proprietários rurais. $\left({ }^{5}\right)$ Naturalmente, êstes devem vender a maior parte dos produtos agrícolas ao Estado. Embora em teoria tais fornecimentos sejam feitos segundo os contratos celebrados entre - Estado e os produtores, na realidade o sistema aproxima-se de uma espécie de tributo. O restante pode ser usado pelo agricultor ou vendido no mercado livre, sujeito - em muitas circunstâncias - à regulamentação de preços determinada pelo Estado. Não obstante, em tais situações as relações contratuais entre as partes são mais ou menos similares às existentes nos sistemas jurídicos tradicionais. Além disso, o artesanato e algumas emprêsas industriais de pequeno porte - embora grandemente assoberbadas com os impostos - foram deixados em mãos de particulares.

Também no setor socializado, o Direito Polonês fala de contratos, significando contratos entre emprêsas estatais. Seriam tais contratos, entretanto, comparáveis aos acôrdos de vontade, geradores de obrigações, no sentido tradicional? É claro que "tal problema não pode ser determinado por rótulos". ( $\left.{ }^{6}\right)$

$\mathrm{Na}$ Polônia de hoje, três espécies de partes podem figurar nos contratos: pessoas naturais, cooperativas e emprêsas estatais. Sujeitas a alguns importantes requisitos a serem discutidos mais adiante, as obrigações contratuais entre os membros do primeiro grupo não diferem daquelas realizadas nos sistemas jurídicos tradicionais. Por outro lado, os contratos avençados entre unidades econômicas socializadas formam um nôvo instituto jurídico. Além dêsses dois extremos,

5. SIEKANOWICZ, "A Terra e o Camponês na Polônia", em 2 GSOVSKI e GRZYBOWSKI, Government, Law and Courts in the Soviet Union and Eastern Europe, (O Govêrno, O Direito e os Tribunais na União Soviética e na Europa Oriental) (1959) 1809. Em 1956, $78,8 \%$ das terras aráveis estavam nas mãos de fazendeiros individuais, $8,6 \%$ pertenciam a fazendas coletivas, e $12,6 \%$ constituíam fazendas governamentais. Id., 1843.

6. SCHELESINGER, The Common Core of Legal Systems (Tarefas Comuns dos Sistemas Legais) -An Emerging Subject of Comparative Study (Um Assunto Emergente em Direito Comparado, em XXth Century Comparative and Conflicts Law - Legal Essays in Honor of HESSEL E. YNTEMA, (1961) 65, 69. O autor continua: "O fato de que duas instituições sejam ambas rotuladas de "contratos" não as faz comparáveis. Nem é a comparação assegurada por similaridades superficiais de normas positivas ou de outros elementos institucionais". E conclui: "Em têrmos funcionais, a comparação de um contrato livre e de um contrato entre emprêsas estatais, que obedecem à planificação, é altamente problemática". 
há situações intermediárias: os contratos acordados entre entidades socialistas de um lado e pessoas naturais ou cooperativas de outro. Muitos dêsses pertencem à primeira categoria. Por exemplo: uma cooperativa compra suprimentos a um armazém governamental. Alguns, todavia, são regulados por regras especiais, desconhecidas nos sistemas jurídicos tradicionais; como, v. g., a "contratação" (contractation, no original) conforme será explicado abaixo.

Em matéria de comércio exterior, o Estado, ou uma de suas companhias, pode celebrar contratos com partes "capitalistas". Em casos tais, é evidente que as regras contratuais tradicionais serão aplicáveis. Com referência ao comércio exterior, "Condições Gerais de Fornecimento de Mercadorias" têm sido adotadas por fôrça de acôrdos internacionais entre os países comunistas. É interessante notar que estas Condições Gerais refletem em larga escala as regras tradicionais do direito contratual.

Nas observações que se seguem, a respeito das obrigações contratuais na Polônia, os contratos tradicionais serão discutidos primeiro. Os "contratos" entre unidades econômicas socializadas serão enfrentados após. Seguir-se-á breve discussão dos contratos internacionais abrangidos pelas "Condições Gerais para o Fornecimento de Mercadorias".

\section{Contratos Tradicionais}

As obrigações derivadas de contrato, no moderno Estado Polonês estiveram sob a égide do Código de Obrigações de 27 de outubro de 1933, pôsto em vigor a $1 .^{\circ}$ de julho de $1934\left({ }^{7}\right)$, suplementado pelo Código Comercial de 27 de junho de 1934, com vigência no mesmo ano. $\left({ }^{8}\right)$ Estas leis polonesas, resultado de muitos anos de árduo trabalho e de cuidadosa elaboração, foram recebidas favoràvelmente no mundo inteiro. Eis o que o grande jurista francês HENRI CAPITANT disse, no seu prefácio à tradução francesa do Código de Obrigações:

"As qualidades de método e de elaboração são inegáveis e salientes mesmo à primeira vista ... Por causa de sua precisão, sua clareza e a concisão de seus artigos, o Código Polonês é muito mais afim do Código Suíço do que do Alemão. Evitou a casuística pesada e desagradável ... Acreditamos que o trabalho será completamente bem sucedido". ( $\left.{ }^{10}\right)$

\footnotetext{
7. Dz. U.R.P. de 28 de outubro de 1933, n.0 82, Poz. 598.

8. Dz U.R.P. de 30 de junho de 1934, n. 057 , poz. 502, emendado.

9. Para detalhes a respeito do trabalho de codificação do Direito Polonês, ver NAGóRSKI, "Codificação do Direito Civil na Polônia, em Estudos de Direito Polonês e Comparado" (1918-1939), (Londres, 1945).

10. NAGÓRSKI, "Projeto de um Nôvo Código Civil para a Polônia", em 1, Estudos da Associação dos Advcgados Po!cneses Exilados nos Estados Unidos" (1956), 51, 52-53.
} 
As relações entre o Código Comercial e o Código de Obrigações foram disciplinadas pelas seguintes disposições do Código Comercial:

Art. $498 \S 1$. Os atos jurídicos de um comerciante, que digam respeito ao funcionamento de sua emprêsa, são atos de comércio.

Art. 499. Se um ato jurídico é comercial para uma das partes, as regras de Direito Comercial são aplicáveis a ambas as partes, salvo disposição em contrário.

Após a Segunda Guerra Mundial, ambos os Códigos permaneceram em vigor, com exceção de algumas disposições que foram revogadas, mas tiveram de ser aplicadas à luz de uma nova lei, os "Princípios Gerais de Direito Civil", decretados primeiramente a 12 de novembro de 1946 ('1), e, em nova versão, a 18 de julho de 1950. $\left({ }^{12}\right)$ Esta lei revogou e modificou muitos artigos do Código de Obrigações na sua parte geral e apenas refundiu alguns outros.

Esta lei e o Código foram as fontes primaciais do Direito Contratual na Polônia até 1965, durante os esforços para a codificação do Direito. $\left({ }^{13}\right)$ Um projeto de Código Civil preparado pelo Ministério da Justiça em 1947-1948 não teve conseqüências. À luz de comentários de um dos teóricos do Direito Socialista, a razão do fracasso foi o fato de o projeto tentar melhorar o velho sistema de Direito em vez de estabelecer nôvo, em conformidade com as condições modificadas da estrutura política e social do Estado $\left({ }^{14}\right)$, e utilizar padrões soviéticos como modêlo para evitar custosas experiências. $\left({ }^{15}\right)$ Em 27 de setembro de 1950, decidiu o Presidium do Govêrno atribuir novamente ao Ministro da Justiça o encargo, juntamente com o da preparação de um nôvo Código Penal. Uma comissão incumbida do anteprojeto foi nomeada pelo Ministro, que se reservou a presidên-

11. Dz. U. N.0 67, poz. 369.

12. Dz. U. de 22 de julho de 1950, N.० 34, poz. 311.

13. Para a apresentação do problema por um juiz da Côrte Suprema da Polônia ver BACHRACH, "Problemas de Legislação e Codificação na Polônia", 4 N. S., O Direito a Serviço da Paz (1965) 85. Para êle, os problemas "diretamente rélevantes" para a legislação e a codificação são "as formas da luta de classes". As considerações importantes para a política legislativa foram as seguintes: "Depois da derrota de grupos isolados de rebeldes, tivemos que enfrentar a resistência e opssição ativas da classe burguesa, mais particularmente dos grandes proprietários de terras no campo e de pequena burguesia nas cidades, a qual, indubitàve!mente menos vital, foi, não obstante, amarga e perigosa. O ataque lançado pela classe inimiga foi mais agudamente sentido nos locais onde o resultado de nossa política tinha sido mais fraco". (86). A preocupação de expressar através do Direito a vontade e os interêsses do povo trabalhador é demonstrativo, precisamente na busca de métodos jurídicos convenientes e na forma que êles assumam (ad. 88). Ver também WASILKOWSKA, Zadania Komisji Kodufikacyinej, (Tarefas a serem enfrentadas pela Comissão de Codificação), 12 Pánstwo i Prawo n.0"1 (1957). O autor salienta que a idéia principal da codificação do Direito Polonês é a "democratização socialista" do Direito.

14. WOLTER, Prawo Cywilne, Czesc Ogólna (Direito Civil, Parte Geral) (1955) 46-47, 2. ed. (1963) item 41.

13. Id. ad 48. Esta observação foi omitida na $2 \cdot^{a}$ ed. 
cia. O projeto ficou pronto em 1954. Seguiram-se as discussões nas revistas jurídicas e durante uma reunião especial de juristas, organizada pela Academia Polonesa de Ciências e pelo Ministério da Justiça, de 8 a 10 de dezembro de 1954, cujos anais foram publicados. $\left({ }^{16}\right)$

Durante três dias de debates houve sete sessões, das quais duas foram devotadas ao Direito de Obrigações; uma tratou do problema do cumprimento de contratos e responsabilidade pelo inadimplemento; outra de algumas questões referentes à compra e venda (law of sales no original).

O princípio tradicionalmente fundamental do Direito de Obrigações, o da liberdade de contratar, foi omitido do Projeto de Código de 1954. Não se fêz sequer a menção de que um contrato é um acôrdo de cumprimento obrigatório entre as partes. Uma obrigação, consoante o Projeto de Código, é um direito do credor de exigir alguma prestação por parte do devedor. O princípio tradicional fôra preservado, com algumas limitações, no projeto de 1948, art. 579, que diz o seguinte:

Dentro dos limites estabelecidos pela lei e, em particular, pelas disposições sôbre planificação econômica, a entrada em vigor e o conteúdo das obrigações contratuais estão sujeitos à livre vontade das partes. $\left({ }^{17}\right)$

O projeto de 1954 não tinha dispositivo semelhante. A omissão foi salientada e criticada durante a discussão de 9 de dezembro de 1954. O Prof. CZACHÓRSKI $\left({ }^{18}\right)$ disse em seu trabalho:

"Parece que o proieto vai longe demais e evita mesmo a mais cautelosa e genérica referência ao efeito da vontade na criação, no conteúdo e no cumprimento de obrigações, dentro dos limites estabelecidos pelos princípios indisponíveis da lei (ius cogens) e, particularmente, pelas regras da planificação econômica. O projeto inclui apenas várias limitações e modificações do princípio da "liberdade de contratar", o qual não está claramente enunciado. As limitações dizem respeito, principalmente, ao intercâmbio entre entidades de uma economia socializada.

A falta de uma disposição geral, fixando o princípio da "liberdade de contratar", parece particularmente infundada

\footnotetext{
16. Materjaly Dyskusyine od Projekłu Kodeksu Cywilnego Polskiej Rzeczypospolitej Ludowej (Material de Discussão para o Projeto do Código Civil da República do Povo da Polônia), 1955.

17. Materialy, supra n. 23 , item 184 .

18. Antigo Diretor da Faculdade de Direito; Vice-Presidente da Universidade de Varsóvia.
} 
no que diz respeito às relações entre pessoas naturais. Em minha opinião, não deveria ser dada grande importância a êsse princípio. Entretanto, sòmente êste princípio pode justificar a existência ... de (alguns) contratos ..." (19)

O Projeto de Código de 1954 sofreu críticas e não foi tido como satisfatório. Em muitos pontos, a crítica inclinou-se em direção oposta à do Prof. CZACHÓRSKI. Foi manifestada a opinião de que o projeto em sua substância não se apartou na medida suficiente da mentalidade tradicional e não levou em consideração o nôvo modo de vida socialista; e a Suprema Côrte da Polônia recusou-se a conceder muita importância às regras estabelecidas pelo Projeto. A Côrte afirmou que o Projeto era meramente a expressão de opiniões da comissão, que o preparara como o melhor método de regular as instituições jurídicas da maneira mais conforme com os fundamentos sociais, econômicos e políticos do presente sistema de govêrno, e acrescentou que não havia razão para acreditar-se que soluções contrárias ao Projeto, fundamentadas nas normas legais presentemente aplicáveis, tais como o Código de Obrigações, contrariassem os princípios do sistema de govêrno e os propósitos da República Popular. $\left({ }^{20}\right)$

O trabalho relacionado com o Código continuou. Foram apresentadas cêrca de trezentas emendas ao Projeto. $\left({ }^{21}\right)$ Um nôvo Projeto foi publicado em 1955, mas não foi convertido em lei. Nova comissão de codificação foi criada pelo decreto de 23 de agôsto de 1956, composta de militantes das lides forenses e de teóricos. $\left({ }^{22}\right)$

Em outubro de 1956, GOMULKA tomou o contrôle do Govêrno, e a maré virou contra o "estalinismo", mas êste acontecimento não exerceu muita influência na moldagem das regras do Direito Contratual. É de notar-se, entretanto, que o Prof. WASILKOWSKI, Presidente da Comissão de Codificação, publicou um artigo sôbre "Problemas da Codificação" $\left({ }^{23}\right)$, no qual salientou que deveriam ser feitas modificações no conteúdo do Direito Civil, Criminal e Processual Polonês, tanto quanto as necessidades da construção socialista exigissem, mas que tôdas as mudanças formais deveriam ser feitas com grande cautela, de modo a conservar todos os benefícios das leis existentes

19. Nos números de 1960 e 1961 de algumas revistas jurídicas polonesas, os Profs. NUCZKOWSKI, WOLTER, JODLOWSKI e GWIAZDORMORSKI travaram uma discussão a respeito da liberdade de contratar. O último asseverou que a liberdade no sentido tradicional não mais existe na Polônia, a despeito do fato de o art. 55 do Código de Obrigações, proclamando-a, ainda não ter sido ab-rogado.

20. Decisão da Côrte Suprema de 25 de maio de 1955,4 Cr. 516/55, O. S. N. 3/56/70; SWIECICKI, ed., Prawo Cywilne z orzecznictwem, literałura i przepisami zwiazkowymi (Direito Civil, com Jurisprudência, Doutrina e Legislação Especial), v. I, (1958) 15.

21. BACHRACH, op. cit. supra n. 13, ad 92.

22. GROSS, Alterações Recentes no Direito e na Organização Judicial da Polônia, 4, Direito ao Serviço da Paz, n. 2 (1957) 110, 112.

23. In Prawo i Zycie (Direito e Vida) n. 19 (1958). 
e da jurisprudência onde ainda parecessem de valor. $\left({ }^{24}\right)$ Para alguns ramos do Direito, as transformações de 1956 tiveram marcada significação. $\left({ }^{25}\right)$

Um nôvo Projeto foi publicado em $1960\left({ }^{26}\right)$ e aceito, em primeira discussão, pela Comissão embora não representasse a palavra final de seus doze membros. O prefácio salienta que a discussão pública do projeto foi recomendada, antes da redação final do texto. Como no Projeto de 1954, não houve no de 1960 dispositivo sôbre a liberdade de contratar. Novos projeto foram publicados em 1961 e 1962; finalmente, um nôvo Código foi aprovado em 23 de abril de $1964\left({ }^{27}\right)$ e entrou em vigor a $1 .^{\circ}$ de janeiro de 1965, ab-rogados o Código de Obrigações e o Código Comercial.

Muitas normas do Direito Contratual, editadas pelo Código, não se afastam de padrões bem estabelecidos do mundo do Direito Codificado e do Direito Polonês de pré-guerra. Seguindo tendência freqüente, uma "Parte Geral" precede as outras partes do Código. No campo dos contratos, a metodologia seguida não parece ser a melhor. Assim, muitos dos dispositivos sôbre contratos (e em particular sôbre a formação dos contratos - arts. 66-81) são encontrados no Capítulo IV (relacionado com os "negócios jurídicos") da Parte Geral, porém, alguns outros são colocados na Terceira Parte: Obrigações (e em particular, no Capítulo III: Princípios Gerais das Obrigações Contratuais - arts. 384-396).

O Código não define contrato, nem obrigação. Entretanto reafirma o direito pré-existente ao enfatizar a vontade das partes. Assim, quando as partes negociam, o contrato só se consuma quando o acôrdo é alcançado em todos os pontos que estão sendo discutidos. $\left({ }^{28}\right) \mathrm{E}$, na interpretação de contratos, a "vontade comum das partes e o objeto

24. Nota, Revista "Direito e Vida" (Prawo i Zycie) 1958, 6 Rev. Contemp. L. (1959) 156, 158.

25. Particularmente sôbre a reorganização dos tribunais (lei de 27 de maio de 1957). "... Alterações foram impostas pela vívida evolução que introduziu em nosso sistema judicial um clima inteiramente nôvo, correspondendo ao conteúdo progressista das modificações que ccorreram na Polônia em outubro de 1956. E êsse nôvo clima encontra expressão no respeito devotado à independência do Judiciário, e a firme determinação, da justiça, na observância do estrito processo traçado em lei". GROSS, op. cit. no n. 22, ad 114. A advocacia foi reorganizada pela Lei de 19 de novembro de 1956. Id. ad 115.

26. Recentes esforços dos poloneses, visando à codificação, foram favoràvelmente apreciados por alguns juristas emigrados. Assim, foi salientada a recente tendência de tornar os trib!!nais "os principais guardiões da legalidade e dos direitos privados". (GRZYBOWSKI, Reforma e Codificação das Leis Polonesas, 7 Am. J. Comp. L. (1958) 393, 398) e que no campo do Direito Penal, à vista de experiências mal sucedidas na União Soviética, "o pensamento jurídico polonês voltou-se para a tradição polonêsa" (ibid.). "As técnicas legislativas, o retôrno às instituições liberais, e uma estimativa realista das condições econômicas e sociais do país indicam que o enfoque da Comissão será cauteloso e livre de antecipação doutrinária do futuro, em têrmos de disposições legais designadas para uma estrutura social ainda inexistente. Conseqüentemente, a ênfase nos requisitos profissionais dos membres da profissão jurídica, quer no Judiciário, quer na advocacia" Id. ad 401.

27. Dz. U. de 18 de maio de 1964, n. 0 16. poz. 93.

28. Art. 72. 
do contrato" devem prevalecer sôbre suas disposições literais. $\left({ }^{29}\right)$ A Côrte Suprema da Polônia decidiu (quando estava em vigor o art. 108 do Código de Obrigações, predecessor da disposição supra do Código Civil), que a mesma regra é aplicável às declarações unilaterais de vontade; portanto, dever-se-ia investigar a intenção da parte ao fazer a declaração e o fim que tinha em mente. $\left({ }^{30}\right)$

O Código não contém um princípio geral da liberdade de contratar. WOLTER declarou que o princípio burguês da liberdade de contratar serve de instrumento aos interêsses do "grande capital", devendo desaparecer em um sistema de economia organizada, onde a idéia anarquista de livre competição é substituída pela planificação socialista. Nas relações entre pessoas naturais, tal princípio deve ser sèriamente limitado, particularmente de modo a não permitir qualquer exploração do homem pelo homem, consoante o modêlo capitalista.

Naturalmente, a regra usual de que os contratos contrários ao Direito são nulos, foi aceita pelo Código; a relevante disposição estende a aplicação da regra a exemplos em que uma parte procurasse elidir a lei. $O$ art. $58 \S 11^{\circ}$ do Código diz o seguinte:

Um negócio jurídico contrário ao Direito ou que objetiva burlar a lei não é válido, a não ser que uma relevante disposição admita outro resultado, e, em particular, que as cláusulas sem validade de um negócio jurídico sejam substituídas por relevantes dispositivos de lei.

A seção seguinte do Código é menos ortodoxa. Modelada segundo dispositivos similares do Direito Soviético e reformulando a regra estabelecida no art. $41 \S 11^{\circ}$ dos Princípios Gerais de Direito Civil de 1950, ○ art $58 \S 2 .^{\circ}$ do Código dispõe que "um negócio jurídico contrário aos princípios da vida social não é válido". Isto enquadra o Direito Contratual Polonês no alinhamento teórico das Democracias Populares. O mesmo têrmo (usado no art. 76 da Constituição de 1952) é encontrado em inúmeras outras disposições do Código. Assim, o art. 94 reza o seguinte:

Uma condição impossível e uma condição contrária ao Direito ou aos princípios da vida social nulifica o negócio jurídico se é uma condição prévia, e é considerada não escrita se é uma condição subseqüente.

Um dispositivo sôbre a interpretação de declarações de vontade tem o mesmo efeito. $O$ art. 107 do Código de Obrigações, do se-

29. Art. $65 \S 2$.

30. Côrte Suprema, decisão de 31 de agôsto de 1948, K. C. $315 / 48$. SWIECICKI, op. cit. ivo n. 20 , v. I, pág. 130.

31. WOLTER, op. cit., no n. 14 págs. $301-302$ (1.a ed.) 
guinte teor: "uma declaração de vontade deve ser interpretada de acôrdo com os requisitos de boa-fé e os costumes de atividade econômica, sendo tomadas em devida conta as circunstâncias nas quais foi expressada", foi revogado, e, em seu lugar, o art. $65 \S 11^{\circ}$ do Código dispõe: "uma declaração de vontade deve ser interpretada de acôrdo ... com os princípios da vida social e os costumes estabelecidos". $\left({ }^{32}\right)$

Ainda uma vez o art. $5 .^{\circ}$ do Código dispõe que "a ninguém é permitido fazer uso de um direito de modo a contrariar seu fim econômico-social ou os princípios da vida social na República Popular Polonesa". Um outro princípio geral, expresso no art. $4 .^{\circ}$, repete a disposição do art. $10^{\circ}$ dos Princípios Gerais do Direito Civil e diz o seguinte: "As disposiçŏes do Direito Civii devem ser interpretadas e aplicadas na conformidade dos princípios do sistema de govêrno e os objetivos da República Popular Polonesa". A mesma idéia é expressa em disposições especiais do Código, tais como o art. $354 \S 11^{\circ}$ :

O devedor deve cumprir a obrigação de conformidade com sua natureza e de modo a corresponder a seus fins econômico-sociais e aos princípios que regem a vida social.....

O nôvo ponto de vista foi comentado da seguinte maneira: "Apesar do fato de que o princípio da liberdade de contratar foi substancialmente reduzido no sistema socialista de govêrno, as partes ainda podem determinar livremente o conteúdo das obrigações dentro de certos limites". $\left({ }^{33}\right)$

Êsses amplos dispositivos tornam possível aos tribunais inter. pretar as leis e também os contratos, como julgarem apropriado. Os tribunais fazem uso freqüente dessas disposições $\left({ }^{34}\right)$, e, assim, existe sempre a possibilidade de que a intenção das partes venha a ser desprezada, ou de que uma disposição legal específica possa ser privada de efeito.

Como exemplo da aplicação do art. $10^{\circ}$ dos Princípios Gerais do Direito Civil, análogo ao art. $4 .^{\circ}$ do Código, pode ser citado um caso de 1950. Contràriamente ao que se dá nos países da common law, em casos de acidentes do trabalho, ou danos causados, à saúde de alguém ou à sua capacidade de prover à própria subsistência, o Código Polonês de Obrigações prescrevia uma indenização pagável

32. Semelhantemente ○ art. 56 estabelece como norma que "um negócio jurídico traz não sòmente aque'as conseqüências sôbre as quais dispõe, mas, também, aquelas que resultam do Direito, dos princípios da vida social e dos costumes estabelecidos".

33. CHANOWICZ e GÓRSKI, Zobowiazania - Czesz Czczególowa (Obrigaçōes - Parte Especial (1959) 4.

34. Um resumo das decisões que aplicaram estas disposições legais é dado em SWIECICKI, cp. cit. no n. 20, em LITWIN, Zasady Spolecznego Wspólzycia w. Orzecznictwie Sadu Najwyzszego (Os Princípios da Vida Comunitária nas Decisões da Côrte Suprema), Nowe Prawo, n.0 12 (1953) 4. 
em parcelas periódicas (uma pensão anual, por exemplo) ao invés de um pagamento único, tarifado $\left({ }^{35}\right)$, mas consentia ao tribunal, em face de razões relevantes, autorizar o interessado a exigir a indenização de uma só vez. $\left({ }^{36}\right)$ Invocando o art. 1. ${ }^{\circ}$ dos Princípios Gerais, a Côrte Suprema recusou-se a referendar o desejo de estabelecer uma emprêsa comercial como "razão relevante". para concessão de uma soma total. A Côrte salientou que a intenção do autor era a de estabelecer uma emprêsa com base em princípios capitalistas, e referindo-se à argumentação de que se tratava de uma "razão relevante" continuou:

"Esta posição relembra idéias que floresceram no cenário do velho sistema econômico, o sistema capitalista, à luz do qual a propriedade do "reduto econômico" de cada um, ou de emprêsas dirigidas sob os princípios do sistema econômico capitalista, foi considerada a melhor garantia da situação financeira de um indivíduo. Nas novas condições do sistema governamental, no sistema social e econômico do Estado Popular, tal posição, naturalmente, não pode ser reconhecida como direito, e a interpretação do art. 164 $\S 1 .^{\circ}$ do Código de Obrigações, baseado em idéias relacionadas com o sistema anterior é indefensável ... A finalidade da instituição da indenização por acidentes não pode ser criação de novos capitalistas.

$\mathrm{Na}$ interpretação dos arts. 161-166 do Código de Obrigações, e, em particular, em conexão com o art. 196 da Lei de Seguros Sociais, isto é, quando o problema é relativo à indenização por acidente do trabalho, deve-se ter em mente, primeiro, que, no sistema de democracia popular, a fonte principal de subsistência para cada um deve ser o trabalho realizado dentro dos limites de possibilidades e capacidades física e intelectual de determinado indivíduo, e, segundo, que o Estado Popular estende sua proteção aos indivíduos inaptos para o trabalho, e, em particular, àqueles que se incapacitaram em decorrência de acidente, e concede-lhes auxílio". $\left({ }^{37}\right)$

Há numerosos casos nos quais o amplo dispositivo do art. $3 .^{\circ}$ dos Princípios Gerais $\left(^{38}\right.$ ) (ou o art. $5^{\circ}$ da versão anterior) foi aplicado

35. Art. 161. A mesma norma foi aplicada aos dan:s atribuídes aos sobreviventes, por terem causado uma morte injusta (art. 162). Os artigos correspondentes do nôvo Código são o $444 \S 2$ e $\circ 446 \S 2$.

36. O art. $164 \S 1$ do anterior Código de Obrigações; o art. 447 do Código Civil.

37. Côrte Suprema, decisão de 14 de novembro de 1950, C. 299/50 - Zb. O. 1/52/11, P. I. P. $8-9 / 51,436$ N. P. $11 / 51 / 39$, P. Z. S. 8-9/51/93, SWIECICKI, op. cit. v. 1, p. 16,

38. Êste foi análogo ao art. 5.0 do Código Civil, porém, mais restrito, pois não teve qualquer referência ao "fim econômico-social". 


\section{BIBILOTECA DE CIENCIAS JURIDICAS}

pela Côrte Suprema e pelos tribunais inferiores. Assim, reconhecendo que o empregador ao despedir um empregado a seu serviço, não tem que apresentar qualquer justificativa, a Côrte Suprema, não obstante, decidiu que tal despedida não será tida como válida se a quebra da relação empregador-empregado não satisfizer os fins sociais da lei que protege o empregado, ou os requisitos da boa fé. $\left({ }^{39}\right)$

Com efeito, o empregador pode ser compelido a manter empregada uma pessoa ainda que não o queira. $\left({ }^{40}\right) \bigcirc$ art. $3 .^{\circ}$ pode, porém, vir contra os interêsses do empregado. Assim, apesar de, por hipótese, um contrato de trabalho, por descuido do empregador, não estar formalmente rescindido, os princípios da vida social não permitirão ao empregado reaver seu salário acumulado, se negligenciou em esclarecer a situação. $\left({ }^{4}\right)$

Num outro caso, envolvendo situação trabalhista, as horas e as obrigaçổes do empregado foram modificadas. A Côrte Suprema salientou que o empregado era "membro de equipe responsável pelo cumprimento de deveres, a serem cumpridos pela emprêsa industrial estatal", e continuou:

"Entretanto, é contrário aos princípios de vida social, da parte do empregado, insistir na letra do contrato e não levar em consideração as necessidades vitais da emprêsa para a qual trabalha, recusar-se a desempenhar, durante um período curto e temporário, deveres plenamente adequa. dos às suas qualificações profissionais, sòmente porque êsses deveres não são idênticos àqueles estabelecidos no contrato, e, em particular, porque lhes falta o caráter de trabalho de direção que estava relacionado com o que fôra contratado". $\left({ }^{42}\right)$

Alguns casos dizem respeito ao problema do despejo. Nesse passo, foi decidido que $\circ$ art. $3 .^{\circ}$ dos Princípios Gerais tornou a validade da notificação de despejo de um apartamento subordinada à consideração do efeito do despejo na vida do locatário e sua família, levando-lhe em conta o número e a idade de seus componentes, etc., ainda que verificados os requisitos legais para a cessação do contrato de locação. $\left({ }^{43}\right)$ O vencimento do prazo de locação do prédio utilizado por uma farmácia, e o pedido de despejo, numa

\footnotetext{
39. Côrte Suprema, decisão de 21 de junho de 1948, C. Prez. 114/48, Zb. O. 3/48/61, P.i.P. 9-10/48/147, P. N. 9-10/48/305, SWIECICKI, op. cit. v. I, p. 22-23.

40. A êsse respeito, O Direito Trabalhista americano pode estar de acôrdo com o Direito polonês.

41. Côrte Suprema, decisão de 16 de outubro de 1953, I.C. 3031/52, P.U.G. 3/54/112, SWIECICKI, op. cit., v. I. p. 32.

42. Côrte Suprema, decisão de 16 de outubro de 1952, C. 1906/52, N.P. 7/53/67, P.U.G. 3/53/104, SWIECICKI, op. cit.. v. I, p. 33

43. Côrte Suprema, decisão de 13 de março de 1956, 1 Cr. 197/56, O.S.N. 4/56/111, SWIECICKI, op. cit., v. I, p. 37-38.
} 
ocasião em que na localidade não haja outra loja adequada, é contrário aos princípios da vida social, prejudicial à sociedade, e não pode prevalecer. $\left({ }^{44}\right)$

Em outro caso, a Côrte Suprema indicou que a ação judicial contra uma pessoa que estivesse na posse da terra e a tivesse lavrado por muitos anos levantaria, necessàriamente, na própria origem, um problema da conformidade do pedido do autor com os princípios da vida social. Em tal caso, a simples declaração de que o autor tem o direito que postula não será suficiente; é necessário estabelecer que, contràriamente às primeiras impressões, nesse caso particular, o proprietário não abuse de seu direito.

Entre outros exemplos de invocação do art. $3 .^{\circ}$, há o caso no qual a Côrte Suprema afirmou que o interêsse social na não-demolição de prédios uma vez edificados é tão grande que tem precedência sôbre o interêsse da pessoa que pede a demolição, mesmo que a estrutura tenha sido construída de má-fé. $\left({ }^{46}\right)$

De acôrdo com os comentários de um dos mais proeminentes doutrinadores dá Polônia de hoie, a fórmula da "boa-fé" usada nos sistemas de direito tradicionais, é muito mais questionável do que as novas disposições gerais das legislações comunistas:

"Na teoria burguesa, as idéias supra são tratadas sob o aspecto moral. Mas, nela, o resultado é mera fraseologia, como o aspecto característico da classe exploradora em sua decadência moral. E não poderia ser de outra forma, porque - objetivo principal da burguesia foi e é a busca do lucro, e o dinheiro é a única medida de valor de um homem. A burguesia não estabelece entre os homens nenhum outro laço a não ser um mero negócio, um "pagamento à vista", isento de qualquer sentimento". $\left({ }^{47}\right)$

O mesmo autor argumenta que as idéias de boa-fé, bons costumes, e os princípios do negócio honesto, "tornam possível ao tribunal, por causa do caráter abstrato dêsses conceitos, elidir as disposições da própria lei burguesa, quando a sua aplicação fôr desvantajosa para o capitalista. A aplicação dos critérios supramencionados tem lugar, acima de tudo, na avaliação dos meios de realizar obrigações contratuais". $\left({ }^{48}\right)$ Êsses critérios "são máscara para o objetivo

\footnotetext{
44. Côrte Suprema, decisão de 7 de dezembro de 1949, C. 1675/49, Zb. O. 1/50/22, P.i.P. $1 / 51 / 145$, SWIECICKI, op. cit., v. I, p. 37-38

45. Côrte Suprema, decisão de 18 de junho de 1954, 1 Cr. 730/54, N.P. 12/54/90, SWIECICKI, cp. cit., v. 1, p. 34 .

46. Côrte Suprema, decisão de 30 de junho de 1951, C. 704/50, Zb. O. 2/52/45, SWIECICKI, op. cit., v. I, p. 36.

47. SZER, Prawo Cywilne, Czesc Ogólna (Direito Civil, Parte Geral) (1955) 26, citando MARX e ENGELS. Na terceira edição, de 1962, os comentários do autor foram refundidos. 48. Ibid. Para o mesmo fim WOLTER, op. cit. in n. 14, itens 61-62.
} 
direto e o mutável espírito do intercâmbio capitalista, particularmente no período de capitalismo monopolista, cujo objetivo é pugnar pela obtenção de lucros os mais elevados possíveis por intermédio da exploração, destruindo e arruinando a maior parte da população do país". $\left({ }^{49}\right)$

Em contraposição a essas "fórmulas abstratas", o autor assevera que a idéia soviética dos "princípios de vida socialista comum" é "um conceito concreto". $\left({ }^{50}\right)$ É "baseado em premissas de moral socialista ... Como categorias éticas aparecem os conceitos de bem e mal, dever e justiça, consciência e honra, que têm caráter geral. A aplicação dêsses princípios gerais de comportamento encontra sua expressão nos assim chamados princípios de vida comum socialista, o que quer dizer, em costumes socialistas". $\left({ }^{51}\right)$ A contrapartida dessa idéia, no Direito Polonês, são os "princípios da vida social". $\left({ }^{52}\right)$ Não há diferença entre êsses princípios e as normas morais. O reflexo dêles é, por exemplo, a "prioridade do interêsse social ou a equiparação do social aos interêsses pessoais". $\left({ }^{53}\right)$ De acôrdo com o autor, o nôvo enfoque "introduziu uma avaliação objetiva do cuidado requerido no intercâmbio socialista". $\left({ }^{54}\right)$

E discutindo a presente regra polonesa da invalidade de alguns negócios jurídicos diz que, em virtude do art. 41 dos "Princípios Gerais", as categorias principais de atos, que se seguem, deveriam ser consideradas nu!as:

"(1) Os atos contrários aos princípios do sistema do govêrno e à estrutura econômica e social do Estado, tais como aquêles que são dirigidos contra os direitos do Estado ou propriedade cooperativa; contrários aos princípios da planificação econômica ao sistema econômico de contabilidade, à "disciplina financeira" ou às leis que regulamentam os preços. (2) Os atos que violem normas legais imperativas, como aquelas que regulam a forma dos contratos, a capacidade legal das partes, proibindo-lhes alguns atos jurídicos, etc. (3) Os atos que transgridam os propósitos das entidades de economia planificada estabelecidas em lei".

Como atos contrários aos princípios de vida comunitária nos Estados Populares, enumera ainda aquêles que fundamentem ou

49. SZER id. item 173.

50. Id. item 26 .

51. Id. item 27 .

52. Id. item 28 .

53. Id. item 29 .

54. Id. item 30 .

55. Id. item 206-208. 
permitam conduta contrária à "moral socialista", e aquêles cujo objetivo é elidir a lei.

Um outro teórico do presente sistema observa que as fontes dêsses princípios são as "normas morais que expressam as convicções da maioria da sociedade, ou do povo trabalhador das cidades e vilas, em sua luta para construir o socialismo e acabar com os remanescentes da estrutura capitalista". $\left(^{56}\right)$ Entretanto, os princípios de vida social não deveriam ser identificados com regras morais, "as quais têm um caráter geral, enquanto os princípios ... são caracterizados pela concreção e a associação dêles com as formas separadas de relações sociais". $\left.{ }^{57}\right)$ No estabelecimento dos princípios, "o papel principal é desempenhado pela consciência de classe dos trabalhadores, tendo hegemonia na sociedade, e sendo conduzida por sua vanguarda - o partido". $\left({ }^{58}\right)$ A "parte mais progressista da sociedade" é a principal responsável pelo seu surgimento, e, então, adquire uma fôrça cogente "sem consideração da atitude passiva ou mesmo da resistência daqueles elementos, que continuam a representar idéias retrógradas ou claramente antagônicas - (remanescentes da classe capitalista $)^{\prime \prime} .\left({ }^{59}\right)$

Contudo, mesmo algumas altas autoridades na Polônia reconhecem que há perigo nessas disposições gerais. Abrindo as discussões sôbre o Projeto do Código Civil de 1954, o Ministro da Justiça, SWIATKOWSKI, expressou a opinião de que os arts. $1 .^{\circ}$ e $3 .^{\circ}$ dos Princípios Gerais capacitam os tribunais a evitar a aplicação de disposições legais que se tornaram obsoletas, e declarou que, em decorrência, algumas leis ficaram sem efeito, mesmo não tendo sido expressamente revogadas. Reconheceu que as decisões judiciais dessa espécie freqüentemente não são uniformes, o que conduz à violação da norma legal, impede os cidadãos de postularem alguns de seus direitos e causa injustiças". $\left({ }^{60}\right)$

Num artigo publicado em uma revista jurídica polonesa, o autor criticou a atitude de alguns tribunais e queixou-se de decisões que mostravam um perigo de "nihilismo legal" por uma descuidada e errônea aplicação do art. $3 .^{\circ}$ dos Princípios Gerais. Essa atitude reflete-se nas referências judiciais aos "princípios de vida social", em tornar claro qual o princípio que está em questão, e sem qualquer análise da situação fática do ponto de vista dos dispositivos de lei aplicáveis. O autor mostrou a tendência perigosa de juízes inexpe-

56. WOLTER, op. cit., in n. 14, item 63 (1.a ed.).

57. Ibid.

58. Id. item 64 .

59. Ibid.

60. Materjaly, supra, n. 16, item 7. 
rientes $\left({ }^{6}\right)$ de substituir tôda a lei pelo art. $3^{\circ}$, e apelou para um esfôrço no sentido de tornar mais concreta a idéia dos "princípios de vida social" ${ }^{\prime \prime}\left({ }^{62}\right)$

Um outro autor admitiu:

"Infelizmente, é necessário declarar que também na doutrina socialista há, até agora, a falta de uma análise satisfatória da forma de normas sociais, que é sugerida pelos princípios de vida social, a despeito do fato de o papel delas ... ser tremendo ... A falta de estudos teóricos resultou em que os tribunais tiveram que examinar caso por caso, em busca de soluções, as quais, algumas vêzes - afortunadamente com pouca freqüência - foram errôneas, levando na verdade ao enfraquecimento da fôrça obrigatória das normas legais com base em suposta repulsa aos princípios de vida social". $\left.{ }^{63}\right)$

Juristas poloneses, que vivem no Mundo Livre, são bastante contundentes em suas críticas. Citando alguns artigos dos Princípios Gerais e da Constituição de 1952, um dêles declara:

"Assim, ambas, a lei ..... e a Constituição demandam uma interpretação política do Direito. Uma lei deveria ser interpretada e aplicada ..... à luz das diretrizes do govêrno na busca do propósito geral do Estado Popular".

Isto introduz o conceito de luta de classe na aplicação do Direito, substituindo objetividade por preconceito. Dêsse modo grande incerteza é criada e a porta é aberta a uma interpretação e aplicação arbitrárias das normas legais. $\left({ }^{64}\right)$

Quanto ao conceito de "vida social no Estado Popular", que substituiu o de boa-fé e sã moral, mas tem uma conotação mais vasta, - autor declara que êste conceito "abriu a porta .... ao arbítrio", e que "êste nôvo método de formação de contratos pode ser sempre usado em detrimento das verdadeiras intenções das partes contratantes".

Um outro autor comenta:

"Êstes princípios abriram caminho para uma "interpretação

61. Vários juízes, $n=$ meados depois da Segunda Guerra Mundial, não tinham qualquer preparação legal adequada.

62. RÓZANSKI, "O Bledach w Orzecznictwie Niektórych Sadów Powiałowych Przy Słosowaniu art. 3 p.o.p.c." (Sôbre os Erros de Algumas Decisões dos Tribunais de Condado na Aplicação do art. 3.0 dos Princípios Gerais de Direito Civil), 11-12 Nowe Prawo (1956) 138; SWIECICKI, op. cit. no n. $20, v .1$, p. 24

63. WOLTER, op. cit., no n. 14, item 61 (2.a ed.)

64. SIEKANOWICZ, Os Contratos na Polônia de Após Guerra, 5 Instantâneos (mimeogr., Libr. of. Congress, 1957) 493, 494-495, e o Capítulo 46 de GSOVSKI e GRZYBOWSKI, Govêrno, Direito e Tribunais na União Soviética e na Europa Oriental, v. II (1959) 1307, 1313. 
livre" dessas noções gerais .... Juízes novos, devidamente doutrinados, e, do mesmo modo, os antigos, forçados a seguir a linha do Partido Comunista, estavam, assim, armados de amplos podêres de interpretação que os habilitaram a dar um nôvo significado a instituições e noções básicas como propriedade, contrato, cumprimento de obrigações, boa-fé e remodelá-las de acôrdo com os requisitos da assim chamada "legalidade socialista" ou "norma de direito socialista". $\left.{ }^{65}\right)$

É interessante notar que, devido à crítica supra, não houve dispositivos paralelos aos arts. $1 .^{\circ}$ e $3 .^{\circ}$ dos Princípios Gerais, no projeto de 1960. Contudo, o conceito de "princípios da vida social" foi mencionado em alguns artigos pormenorizados do Projeto. A idéia reapareceu, em todo o seu alcance, na redação de 1962.

O estudo do presente Direito Contratual Polonês, da mesma forma que o Direito de outros países comunistas, deveria ser empreendido tendo-se em mente $\circ$ efeito dêsses princípios. A aplicação dêsses princípios pode ter influência, numa situação fática concreta, sôbre normas específicas, aparentemente neutras, tais como aquelas que tratam da oferta e aceitação.

Um outro ponto deve ser estabelecido. Uma quantidade cada vez menor de leis da pré-guerra está ainda em vigor. A Côrte Suprema da Polônia deixou claro ${ }^{\left({ }^{6}\right)}$ ) que elas permaneciam pela vontade do "legislador popular", são uma parte do sistema legal do "Polônia Popular", e devem ser toleradas, a não ser quando sejam contrárias aos princípios do sistema de govêrno ou aos propósitos do Estado Popular. $\left({ }^{67}\right)$

A. questão surge quando se procura saber se e em que extensão as decisões judiciais de pré-guerra são plenamente invocáveis na Polônia de hoje. Êste problema foi discutido pela Suprema Côrte da Polônia, em 1948, e o Plenário estabeleceu a seguinte resolução:

"Considerando que .... uma distinção deveria ser feita, do ponto de vista do presente sistema de govêrno, entre essas decisões judiciais e êsses princípios legais, em vigor no período compreendido entre as duas guerras, que ainda são aplicáveis e aquelas e aquêles que já não o são devido à

65. NAGÓRSKI, "Projeto de Um Nôvo Código Civil para a Polônia", em Estudos da Associação Polonêsa de Advogados Exilados nos Estados Unidos, v. I, (1956) 51, 57.

66. Côrte Suprema, decisão de 5 de dezembro de 1950, C. 323/50, 8-9 Panstwo i Prawo 420 (1951); S. N. 30 de junho de 1951, C. 649/50,Zb. O. 2/52/44, 2 Panstwo i Prawo 312 (1952); SWIECICKI, op. cit., v. I, p. 12.

67. Ver 0 art. 1.0 dos Princípios Gerais de Direito Civil e 0 art. $4.0^{\circ}$ do atual Código Civil, supra. 
remodelação do Estado Polonês, não podendo assim ter influência sôbre as atuais decisões judiciais dos tribunais polonêses,

O Plenário da Côrte Suprema resolve:

1) reconhecer ..... que as decisões da Côrte Suprema e os princípios legais do período de entre-guerras (1918-1939), que são contrários ao presente sistema de govêrno e às leis em vigor, têm hoje, apenas, um significado histórico;

2) declarar que sòmente aquêles princípios legais e decisões judiciais do período de entre-guerras mencionado, que não contiverem esta contrariedade, constituem ainda Direito vigente;

3) confiar a avaliação de uma dada decisão judicial ou princípio legal e sua classificação no primeiro ou segundo ponto da presente resolução, aos juízes competentes em cada caso, ficando a questão de se saber se esta avaliação é bem fundada sujeita ao contrôle normal dos tribunais superiores". $\left({ }^{68}\right)$

A despeito desta resolução, tanto os tribunais como os autores, relutam bastante em citar qualquer decisão judicial polonesa de pré-guerra.

Com as reservas acima, as normas legais concernentes a contratos entre indivíduos, em vigor na Polônia, são comparáveis às normas correspondentes nos sistemas legais tradicionais. Muito embora o princípio da liberdade de contratar não seja expressamente reconhecido, será permitido às partes regular as relações entre si substancialmente de acôrdo com suas vontades, tanto quanto o Estado não estiver interessado no objeto do acôrdo.

\section{Contratos Entre Unidades Econômicas Socializadas.}

É concebível regular tôda a vida econômica de um país e as relações entre suas emprêsas industriais e comerciais por um conjunto de decretos e determinações governamentais, sem qualquer margem para negociações entre as entidades envolvidas. Na realidade, tal sistema já foi tentado na Rússia, não tendo, porém, funcionado. Mesmo os teóricos da economia planificada admitem que o sistema jamais foi executado de uma forma pura, pois "êle falha à luz da impossi-

68. Sessão Plenária da Côrte Suprema de 25 de novembro de 1948 - Panstwo i Prawo 210 (1949), 12 Demokratyczny Przeglad Prawniczy 58 - (1948), 3-4 Przeglad Notarjalny 184 (1949), 4 Przeglad Ustawodwstwa Gospodarczego 84 (1949), SWIECICKI, op. cit., em n. 20, v. I, p. 11-12. 
bilidade de eliminar a influência da lei de valôres". $\left({ }^{69}\right)$ Por outro lado, o sistema econômico da lugoslávia é baseado num mercado razoàvelmente livre; a diferença entre um sistema "capitalista" e êste tipo de regime socialista jaz principalmente na natureza da propriedade das emprêsas. $\left({ }^{70}\right)$ O tipo mạis comum de sistema socialista é aquêle no qual a vida econômica do país é baseada em curioso conjunto de normas - uma mistura de Direito Administrativo e de Direito Contratual, o primeiro prevalecendo nas relações entre as emprêsas socialistas e as repartições coordenadoras do Estado, ao passo que o outro (isto é, o Direito Contratual) governa as relações das entidades inter se. $\left({ }^{71}\right)$ Contudo, como será visto, êsse Direito Contratual tem um sabor especial, desconhecido dos sistemas legais tradicionais.

A aplicação de tôdas as normas gerais de Direito Contratual aos contratos de emprêsas de propriedade do govêrno é dificilmente concebível. Na verdade, mesmo antes que a totalidade do Código de Obrigações tivesse sido revogada, a aplicabilidade de suas disposições a "contratos que são criação da economia socialista" teve que ser enfrentada à luz do art. $1 .^{\circ}$ dos Princípios Gerais de Direito Civil, e antes que pudessem inspirar confiança, uma investigação teve que ser feita a cada passo para se saber se deveriam ter efeito. $\left({ }^{72}\right)$

$\mathrm{Na}$ Polônia, como em outros países comunistas, normas especiais têm sido decretadas quanto aos contratos entre unidades econômicas socializadas e quanto ao método de dirimir disputas que possam surgir entre elas. Procurando chegar a conclusões quanto às similaridades e dissimilaridades entre êsse conjunto de normas e o Direito Contratual dos países não-comunistas, devemos proceder com cautela. A comparação limitada a certas normas específicas pode revelar que algumas delas são semelhantes; uma relação de Direito Civil pode ser reconhecida como existente entre "organizações socialistas" ou emprêsas, "mesmo se uma delas, não desejando celebrar contrato com outra, foi compelida a assim agir pela decisão de uma comissão de arbitragem" $\left({ }^{73}\right)$; mas, daí não se segue que as instituições em exame sejam equivalentes. Nos sistemas legais tradicionais não há economia planificada; a vida econômica da nação assenta, em geral, na iniciativa privada. Naturalmente, pode haver contratos com o Estado; porém, os princípios gerais do Direito Contratual ser-lhe-ão aplicáveis. $\left({ }^{74}\right)$ "O Direito Contratual, como o Ocidente o conhece, é um

69. BUCZKOWSKI, Zagadnienia Prawo "Modelu" Gospodarski Socjalistycznej (Problemas Legais de Economia Socialista "Modêlo"), 13 Panstwo i Prawo, v. I (1958) 786, 790.

70. Ibid.

71. Ibid.

72. Côrte Suprema, decisão de 25 de maio de 1955, Cr. 516/55, O.S.N. 3/56/70; SWIECICKI, op. cit. no n. 20, v. I, p. 14

73. MIHALY, $O$ Papel das Instituições de Direito Civil na Direção de Economias Comunistas; A Experiência Húngara, 8 Am. J. Comp. L. (1959) 310, 311.

74. Contudo, algumas normas específicas aplicáveis aos detalhes da transação podem ser diferentes daquelas prevalecentes em cutros contratos. 
instrumento da sociedade liberal e de uma economia de mercado livre". $\left({ }^{75}\right)$

O próprio fato de que nos países comunistas há um ramo especial do Direito que trata dos contratos de economia planificada (mesmo que possam estar consolidados em um Código Civil geral), enquanto outras normas são aplicáveis aos negócios entre particulares, fornece alguma prova de que é um nôvo ramo, não tendo contrapartida no Direito de outros países; abrange situações que sòmente podem surgir nos sistemas comunistas. É claro que, às vêzes, as normas em vigor em ambas as situações podem ser as mesmas. Assim, o Código Civil Tcheco-Eslovaco de 1950, substituído pelo nôvo Código de 1964, fala de "responsabilidades surgidas do exercício do plano econômico unificado" conforme o disposto no art. 212(2) pelo qual "na falta de outra disposição, as relações jurídicas que surjam dessa maneira deverão ser reguladas por esta lei“. Mesmo assim, a aplicação das normas pode ser diferente. $O$ mais importante objeto dos contratos da economia planificada será executar o plano, e não conceder efeito à intenção e expectativa das partes contratantes $\left({ }^{76}\right)$, as quais serão, usualmente, instrumento do Estado. $\left({ }^{77}\right)$

Nos últimos anos, na União Soviética e em outros países comunistas têm havido freqüentes discussões sôbre se deveria o Código Civil geral regular apenas as relações entre os particulares, deixando todos os problemas relacionados com as emprêsas estatais para ser objeto de leis especiais, ou se algumas disposições do Código Civil poderiam ser aplicadas a tôdas as espécies de atos jurídicos. No momento, a tendência está fixada na última direção.

Em julho de 1960, foram publicados em Moscou, os projetos dos "Princípios Gerais de Direito Civil" e de "Processo Civil". Depois de discutidos e emendados, foram tornados lei (em 8 de dezembro de 1961) pelo Soviete Supremo. Os "Princípios" servem como ponto de partida para os códigos civis e outras leis nas várias Repúblicas da União Soviética, e exercem uma forte influência no Direito de outros países comunistas. $\bigcirc$ art. 2. ${ }^{\circ}$ dos "Princípios Gerais de Direito Civil" e o art. 2. ${ }^{\circ}$ do Código Civil Russo, de 11 de junho de 1964, dispc̃em que, pela legislação civil são reguladas as relações:

75. MIHALY, id., item 310 .

76. "Mesmo quando há uma similaridade superficial de normas, é claro que a função social de um contrato entre duas emprêsas estatais executoras de um plano, cperando sem referência ao mercado, é muito diferente daquela de um contrafo numa sociedade, onde os ajustes de indivíduos e de grupos oferecem o principal mecanismo para dar efeito aos próprics desej:s e preferências ... Em têrmos funcionais, a comparação de um contrato livre e de um contrato entre emprêsas estatais executoras de um plano, é altamente problemática". SCHELESINGER, op. cit., supra, n. 6, item 69.

77. "O Diretor de uma emprêsa, seus líderes e os trabalhos coletivos (work-collectives, no original), não são, na verdade, os donos da emprêsa; êles são executores de planos obrigatórios". MIHALY, op. cit. no n. 73, item 327. 
- entre o Estado, as cooperativas e as organizações públicas umas com as outras;

- entre os cidadãos e o Estado, as cooperativas e as organizações públicas;

- entre os cidadãos uns com os outros. $\left({ }^{78}\right)$

O Código Polonês segue o mesmo modêlo, e tenta mesclar o Direito Econômico com o Direito Civil Geral. Em sua primeira disposição, o Código $\left({ }^{79}\right)$ proclama que "regula as relações de Direito Civil entre entidades de economia socializada, entre indivíduos e entre unidades de economia socializada e indivíduos". Contudo, em muitos pontos faz exceção às disposições gerais e dita normas especiais aplicáveis a estas unidades. Tais são, em particular, as disposições sôbre - "Dever de Celebrar Contratos Entre as Unidades de Economia Socializada". $\left({ }^{80}\right)$ O Código torna claro que estas normas especiais são aplicáveis às "instituições e organizações sociais dos trabalhadores, cujo dever consiste em executar a atividade econômica" $\left({ }^{81}\right)$, enquanto - salvo disposição em contrário - as normas do Código referentes às pessoas naturais são aplicáveis às pessoas jurídicas que não sejam unidades de economia socializada. $\left({ }^{82}\right)$ Logo após estabelecer essas regras, o Código dispõe que em caso de necessidade o govêrno pode regularizar o intercâmbio entre as unidades econômicas "de certa forma em contrário às disposições dêste Código". $\left({ }^{83}\right)$ Assim, a anterior e a futura legislação, mas os decretos nesse campo, ficaram ratificados e as normas do Código têm apenas um caráter "subsidiário". mentou:

autor de importante e recente tratado sôbre Obrigações co-

"Os mais importantes (problemas) dizem respeito a obrigações das unidades de economia planificada. Os princípios, de acôrdo com os quais devem ser reguladas essas relações jurídicas, são essencialmente diferentes dos princípios de obrigações no enfoque do Código de Obrigações como legislação no período de pré-guerra, porque os fundamentos das legislações do tipo socialista, que regulam as relações jurídicas entre as entidades de economia

78. Disposições similares são encontradas nos novos Códigos Civis das seguintes Repúblicas Soviéticas, os quais entraram em vigor em 1964: Ucrânia, Uzbek, Látvia, Kazakh, Turkmen e Tajik.

79. Art. 1.0 § 1.0 .

80. Art. 397-404.

81. Art. $1.0 \S 2.0$.

82. Art. $1.0 \S 3.0^{\circ}$,

83. Art. 2.0. 
planificada, são diferentes das premissas tradicionais do Direito de Obrigações no período capitalista". $\left({ }^{84}\right)$

Em 1954, o Ministro da Justiça polonês declarou que a instituição legal sacialista denominada "contratação" (contractation no original) é uma das principais formas de executar a união econômica entre a cidade e o campo, embora seja desconhecida nos sistemas legais tradicionais. $\left({ }^{85}\right)$ A mesma observação é aplicável a outros tipos de contratos em economia planificada.

A lei básica relacionada com êsses contratos foi o Estatuto de 19 de abril de 1950, sôbre contratos planificados em uma economia socializada. ( $\left.{ }^{86}\right)$ A lei foi suplementada por uma ordem executiva do Presidente da Comissão Estatal para a Planificação Econômica, de 15 de maio de 1953. $\left({ }^{87}\right)$

Contràriamente aos princípios do tradicional Direito Contratual, que não impõem a ninguém um dever de ingressar na relação contratual, exceto em raras oportunidades, o art. $2 .^{\circ}$ da lei supramencionada exigiu que as emprêsas estatais e aquelas controladas pelo Estado concluíssem acôrdos planificados de maneira a cumprirem seus deveres na execução do planejamento econômico. Esta disposição, compreensível no sistema de Direito onde foi legislada, ilustra bem a principal diferença entre os dois campos do Direito Contratual. O Presidente da Comissão Estatal Para o Planejamento Econômico estabelece uma lista das instituições econômicas superiores que tomam parte nos acôrdos gerais $\left({ }^{88}\right)$, enquanto as unidades inferiores

84. CHANOWICZ, ZOBOWIAZANIA - Czesc Ogólna (Obrigações - Parte Geral) (1958) 4. O Prof. KATZAROW, em seu artigo sôbre "A Planificação como Problema Jurídico", 10 Rev. Int. Dr. Comp. (1958) 298, salientou que o planejamento econômico estabeleceu algumas "novas instituições legais", e, em particular uma "superfonte" do Direito de Obrigações, que é o plano econômico. O objetivo dessa "superfonte" é o "desenvolvimento e a limitação da norma de nulidade do Direito Clássico de forma a obter uma mudança, e não uma anulação, de todos os direitos e obrigações que impedem o desenvolvimento do plano" (ítem 309). Êle declara que o nôvo sistema poderia trazer "a subs tituição do Direito Contratual pelo Direito Administrativo, e dos contratos por ordens administrativas". Contudo, êste enfoque não foi adotado. Junto com a nacionalização e as medidas de socialização, alguma atividade de direito privado foi reservada para as emprêsas estatais, as quais têm personalidade separada da do Estado. Portanto, o plano econômico como uma "superfonte" do Direito de Obrigações "pode modificar ou anular relações legais ou contratuais, mas sòmente sob a condição (1) que essas relações sejam contrárias ao desenvolvimento do plano, e ... sòmente durante o tempo (2) ... e a um grau (3) que pareça necessário ao cumprimento do plano ... Segue-se que a elevação do plano econômico do Estado ao nível de fonte de obrigaçṍes é uma nova fase da penetração do Direito Público no campo do Direito Contratual, especial. mente nas relações entre as emprêsas estatais..." (item 310). Segue-se também que "o plano Econômico ... torna-se a fonte do Direito Contratual à qual o verdadeiro Direito Contratual, criado pelas partes contratantes, é subordinado. Tudo o que, em um contrato, está em desarmonia com o plano econômico ... deve ser retificado ou declarado nulo" (item 311). Para uma recente e completa discussão sôbre alguns aspectos dos contratos em uma economia planificada, ver LOEBER, Planejamento e Execução de Contratos no Direito Soviético, 1964, III. L. Forum 128.

85. Małerjaly, supra n. 16, item 6. Para as disposições sôbre contratação no Código Civil, ver art. 613-626.

86. Dz. U. n. 21, poz. 180 (1950).

87. Mon. Pol., Ordem 28/1953, poz 109.

88. Tais acôrdos gerais ou contratos são preferidos na União Soviética e em muitos outros Estados de economia planificada. Contudo, "a introdução do contrato geral não cbteve muito sucesso na Hungria".

MIHALY, op. cit. no n. 73, item 317. 
concluem acôrdos minudenciados entre si (art. 7). Contratos diretos, sem acôrdos gerais, são possíveis em alguns casos (art. 10).

A lei estabeleceu expressamente que os contratos da economia planificada estejam em conformidade com o planejamento econômico do Estado e com os interêsses da economia nacional (art. 18). Em caso de violação dessa exigência, a Comissão Estatal de Arbitragem pode modificar os contratos, ou, mesmo, declará-los inteiramente sem validade (art. 20). Nenhuma disputa relativa a contratos da economia planificada é julgada pelos tribunais. Êles devem ser submetidos a arbitragem, de acôrdo com o processo legal.

Algumas das disposições da lei foram incorporadas, com ou sem modificações, ao Projeto de Código de 1954. Muitas disposições da própria lei foram criticadas, e ela foi substituída pelo Decreto de 16 de maio de 1956, sôbre Contratos de Fornecimentos Entre as Unidades Econômicas Socialistas. $\left({ }^{89}\right)$ É natural que a nova lei tivesse os mesmos objetivos que a velha; não tendo introduzido nenhum afastamento do enfoque geral dos contratos em um sistema de economia planificada. $O$ art. $1 .^{\circ}$ do Decreto estabeleceu a norma de que as relações entre as unidades econômicas socialistas são baseadas em contratos, porém, naturalmente, a obrigação de contratar e outras, características da economia planificada, tiveram de ser mantidas. $\left({ }^{90}\right)$ Parece, contudo, que sob o Decreto, as normas do Código de Obrigações foram mais prontamente aplicadas do que sob as leis anteriores. $\left({ }^{91}\right)$ O Decreto foi suplementado por uma Portaria do Presidente da Comissão Estatal para o Planejamento Econômico, de 15 de outubro de 1956. $\left({ }^{92}\right)$ Essas normas não continham disposições que constituíssem uma contrapartida direta dos arts. $7 .^{\circ}$ e 10 da antiga lei. Um dos artigos dispôs sôbre a possibilidade da conclusão de contratos por ordens administrativas:

Em casos excepcionais, baseados na necessidade econômica - Conselho de Ministros pode autorizar os órgãos de chefia da administração estatal a expedir ordens para que as unidades de economia socialista subordinadas façam entregas a outras unidades econômicas socialistas, sem que um contrato tenha sido celebrado entre elas. Essas ordens criam direitos e deveres para o recebedor e para o fornecedor, como se um contrato tivesse sido feito entre êles. $\left({ }^{93}\right)$

89. Dz. U. de 30 de maio de 1956, n. 16 , poz. 87.

90. O art. 2.0, § 1.0 diz $\circ$ que segue "As Unidades de Economia Socialista têm a obrigação de participar de contratos de fornecimento tendo como objetivo o cumprimento dos fins planejados".

91. SIEKANOWICZ, op. cit. no n. 64, item 501

92. Mon. Pol. de 2 de novembro de 1956, n.0 98, poz. 1016.

93. Art. 7.0. 
Como interessante exemplo dos modos em que os negócios entre particulares diferem daqueles entre organizações socialistas, pode ser citada a questão das obrigações entre vendedores e compradores.

Um dos trabalhos lidos durante a discussão do Projeto de Código, em 1954, tratou de dispositivos a respeito de venda, e seguiu-se um animado intercâmbio de pontos de vista. De acôrdo com o enfoque tradicional, "contrato de compra e venda é aquêle em que o vendedor concorda na transferência da propriedade para o comprador em virtude de uma contraprestação chamada prêço" $\left({ }^{94}\right)$, enquanto o acôrdo de transferência é um acôrdo por meio da qual o vendedor transfere no momento a propriedade ao comprador. $\left({ }^{95}\right)$

Nos países comunistas tôdas as emprêsas importantes pertencem ao Estado, e seus bens pertencem ao Estado. Isto torna difícil falar-se em uma transferência de titularidade. Como pode, aí, haver uma venda, no sentido tradicional, se ambas são instrumento da mesma pessoa (o Estado) e se os contratos de venda não estão sujeitos à livre vontade das partes, mas são obrigatórios, e se o objeto dêle não é transferir a propriedade do vendedor para o comprador? Um comentador deu esta resposta:

"Êste tipo de compra e venda ... é apenas uma função pública ou social tendo como único propósito executar o plano econômico. Êstes "contratos" são os tìpicamente submetidos ao Plano e as partes, que têm a obrigação de fazê-los e sujeitar-se a êles, não têm pràticamente possibilidade de decidir sôbre seu conteúdo. São ditados pelo plano econômico, por numerosos regulamentos administrativos e, finalmente, estabelecidos em detalhes completos pelos "contratos modêlo" preparados e emitidos pelas autoridades competentes". $\left({ }^{96}\right)$

Em conexão com isto, disposições concernentes ao preço de venda parecerão interessantes:

(1) Os preços estabelecidos no dia da entrega serão aplicáveis;

(2) As partes não podem estabelecer os preços de uma forma contratual, exceto em casos em que forem autorizadas a assim agir pelos regulamentos relativos a preços. $\left({ }^{97}\right)$

O Projeto de Código de 1954 delineou a distinção entre vendas, no sentido tradicional, e as celebradas entre unidades de economia

94. Lei Uniforme de Vendas, Sec. 1(1). Contudo, o momento da transferência de título pode ser diferente em vários sistemas legais.

95. Id. Sec. I, (2).

96. NAGÓRSKI, op. cit. no n. 65 , item 75.

97. § 54 do Anexo à Ordem Executiva de 15 de outubro de 1956, supra, n. 92. 
planificada. Na primeira situação, o Projeto de Código repetiu substancialmente o art. 294 do Código de Obrigações, dispondo que em um contrato de compra e venda "o vendedor obriga-se a transferir ao comprador a propriedade dos bens, e o comprador obriga-se a pagar o preço". ${ }^{98}$ ) (Grifo do autor.) O art. 294 do Código de Obrigações incluía na definição a venda de um direito de propriedade, enquanto que no Proieto de Código havia um artigo separado sôbre êste ponto $\left({ }^{99}\right)$, estabelecendo normas sôbre a venda de bens aplicáveis à "alienação de direitos", tendo sido omitida a palavra "propriedade".

Por outro lado, o art. 456 \& 2 do Projeto de Código de 1954 dispôs que "por um contrato de compra e venda entre emprêsas estatais o vendedor obriga-se a entregar as mercadorias ao comprador e o comprador obriga-se a pagar o preço". (Grifo do autor.)

A dualidade das definições de venda foi criticada $\left({ }^{100}\right)$ com base em que a última definição restringiu indevidamente os deveres do vendedor e que o velho enfoque do Código de Obrigações era flexível o suficiente "para ser inteiramente aplicado nos diferentes tipos de vendas que têm lugar em negócios jurídicos socialistas". $\left({ }^{101}\right)$ Foi salientado que não sòmente bens, mas, também, vários direitos, como a propriedade literária ou as marcas registradas e patentes de invenção, podem ser objeto de venda. Mesmo se assim fôra, e, mesmo que os negócios jurídicos entre emprêsas socializadas fôssem chamados de vendas, certamente seriam vendas de particular espécie, não tendo contrapartida nos sistemas legais tradicionais. A despeito de suas peculiaridades, contudo, êsses atos jurídicos são chamados "compra e venda" nos países comunistas, e algumas normas tradicionais do contrato de compra e venda lhes são aplicáveis.

O Projeto de Código de 1960 reteve a dualidade de definição de compra e venda fixada no Projeto de 1954. O art. 456 do Projeto de 1960 diz o que se segue:

$\S$ 1. Por um contrato de compra e venda o vendedor obriga-se a transferir ao comprador a propriedade dos bens e a entregar os bens ao comprador, e o comprador obriga-se a receber os bens e pagar o preço ao vendedor $\S 2$. Nas vendas entre organizações estatais o vendedor obriga-se a entregar os bens ao comprador e a deixá-los à sua exclusiva disposição, e o comprador obriga-se a receber os bens e a pagar o preço ao vendedor.

98. Art. $456, \S 1$.

99. Art. 468.

100. NOWAKOWSKI, Materialy, supra, n. 16, item 289.

101. Id. item 288. 
Mas nem todos os contratos de economia planificada são feitos entre emprêsas estatais. Alguns dêles têm como partes, de um lado, unidades de economia socializada, e, de outro, particulares. Um contrato típico, dessa espécie é chamado, seguindo-se estritamente o modêlo russo $\left({ }^{102}\right)$, "contratação". (Vide supra.) O objeto dêsse contrato é a venda compulsória de produtos agrícolas ao Estado. Não é permitido ao produtor colocar seus produtos no mercado livre. O produtor pode ser ou um indivíduo ou uma unidade econômica socializada. $\left({ }^{103}\right)$

O texto final do Código Civil não introduziu mudanças substanciais. O texto do art. 456 do Projeto de 1960, renumerado como art. 479 no Projeto de 1962, abriga-se no art. 535 do Código, com apenas uma modificação: as palavras "nas vendas entre organizações estatais" foram substituídas por "nas vendas entre unidades organizacionais estatais". Mais uma vez, o capítulo sôbre contratos de economia planificada $\left({ }^{104}\right)$ confirma as normas pré-existentes. O Código permite ao Conselho de Ministros ou a um órgão de chefia da administração estatal, agindo sob sua autoridade, "estabelecer condições gerais ou padrões de contratos para uma espéscie definida de contratos entre unidades econômicas socializadas e entre essas unidades e outras pessoas". $\left({ }^{105}\right)$

A análise minudente dos contratos de economia planificada na Polônia requer um estudo especial. Sòmente uma pequena parte de tal estudo cobriria pontos que podem ser expressos na linguagem tradicional do Direito Contratual. Um sistema dêsses contratos existe em todos os países comunistas, com variações diversas. Não há contrapartida nos sistemas legais tradicionais.

As disputas que envolvam contratos de economia planificada escapam à jurisdição dos tribunais gerais e são submetidos à arbitragem, seguindo o modêlo da União Soviética, aceito em outros países comunistas. $\left.{ }^{106}\right)$

\section{Condições Gerais Para a Entrega de Bens.}

Uma fonte adicional do Direito Polonês, e, mais geralmente, do Direito Contratual comunista, particularmente no campo da compra

102. NAGORSKI, op. cit. no n. 65, item 73.

103. Para uma discussão em inglês dêsse tipo de contratos, ver SIEKANOWICZ, op. cit. no n. 64, 502-505.

104. Ver supra, n. 80

105. Art. $384 \S 1$.

106. Vide GRODECKI, "Arbitragem Econômica Estatal na Polônia", 9 Int. Comp. L. Q. (1960) 177. Para a distinção entre o procedimento judicial e arbitral, ver TYCZKA, Droga Pos. fepowania Arbitrazowego (O Modo de Arbitragem), Panstwo i Prawo (1955) 588 . Em geral, a mais importante função da arbitragem em países socialistas é fazer cumprir o plano econômico. Por arbitragem é possível "modificar ou anular relações contratuais existentes, ou então dar condições para a criação de tais relações, em outras palavras, à perfeição de contratos entre as várias emprêsas ou entre elas e o próprio Estado". KATZAROV, op. cit. n. 84, item 313. Ver também KUFEL e TYCZKA, Postepowanic Arbitraziowe (Procedure in Arbitration), 1963. 
e venda, é um documento redigido em 1957 (assinado em 13 de dezembro) e aplicável aos contratos de compra e venda e concluídos em $1 .^{\circ}$ de janeiro de 1958, ou após, entre a organização de comércio exterior dos Estados Membros do Conselho de A.juda Econômica Mútua (COMECON). Oito países de economia planificada participaram dêsse acôrdo, chamado "Condições Gerais Para a Entrega de Bens": Albânia, Bulgária, Tcheco-Eslováquia, República Democrática Alemã, Hungria, Polônia, Romênia e U.R.S.S., aderindo, em 1962, a Mongólia. $\left({ }^{107}\right)$

As condições gerais constituem a unificação das normas sôbre compra e venda nos negócios entre os países supramencionados. Baseiam-se na experiência ganha em prévios acôrdos bilaterais entre os Estados comunistas $\left({ }^{108}\right)$ e são aplicáveis salvo quando as partes acordarem que "devido à natureza específica dos bens e/ou a características especiais de entrega, um afastamento de disposições particulares ... seja exigido". $\left({ }^{109}\right)$

Igual a projetos similares preparados pelo Instituto de Roma Para a Unificação do Direito Privado e pela Conferência de Haia, as Condições Gerais não pretendem substituir o Direito Local dos Estados participantes, e são aplicáveis sòmente no comércio exterior. A natureza legal das Condições Gerais não é muito clara. Alguns autores de Direito consideram-nas um tratado internacional multilateral $\left({ }^{110}\right)$, outros - como simples recomendações $\left({ }^{11}\right)$ porquanto não foram acordadas e devidamente ratificadas em consonância com os processos seguidos nas convenções internacionais.

Seguindo o padão usual comunista, as Condições Gerais dispõem que "tôdas as disputas que possam surgir de ou em conexão com - contrato serão sujeitas a arbitramento, (sendo excluída a jurisdição dos tribunais gerais), num tribunal arbitral estabelecido para tais disputas no país do réu". Contudo, se as partes concordarem, a disputa pode ser submetida a um tribunal arbitral de um "terceiro País-Membro do Conselho Para Ajuda Econômica Mútua". (172)

É de se notar "que cada país de economia planificada tem um tribunal permanente de arbitragem para o comércio exterior o qual é, em vários aspectos, igual a um tribunat judiciário. (113) Disposições

107. GRZYBOWSKI, "A Comunidade Socialista de Nações", 57, 59 (1964).

108. BERMAN, "A Unificação das Cláusulas Contratuais no Cómércio entre Países Membros do Conselho para o Mútuo Auxílio Econômico", 7 Int. \& L. Q. (1958) 659. O texto das Condições Gerais foi tirado dêsse artigo. Ver' também BYSTRICKY e LANDA, "A Unificação das Leis de Venda (Sale) Internacional", 6 Rev. Contemp. L. (1959) 67.

109. Preâmbulo às Condições Gerais.

110. EX., JAKUBOWSKI, "A jednak ius cogens", Handel Zagraniczny 28 (1960), citado por GRZYBOWSKI, supra.

111. BYSTRICKY e LANDA, id. item 73.

112. § 65.

113. BERMAN, op. cis. n. 108, ítem 664. 
substantivas das "Condições Gerais" poderiam fàcilmente ser aplicadas às transações entre países "capitalistas". Na verdade, o planejamento econômico e a especialização prevalecem no interior do grupo inteiro de signatários; porém, isto não se reflete nas "Condições". A situação é mais ou menos comparável àquela dos sistemas internos dêsses países, onde os ministérios, várias comissões e outras reparrições de bem desenvolvido aparelho burocrático dirigem e controlam tôda a vida econômica em cada estágio e a todo o tempo.

Em conclusão, deve ser salientado que no setor privado as normas do Direito Contratual Polonês não diferem substancialmente do Direito de outros tradicionais sistemas legais, com exceção de algumas cláusulas gerais que, se deturpadas pelos tribunais, podem contrariar os princípios de outras disposições legais. Contudo, no setor dos atos jurídicos entre emprêsas socialistas, desenvolveu-se um conjunto especial de normas. Mesmo que algumas delas possam, em têrmos, ser similares ou exatamente as mesmas daquelas do setor privado (e podem, na verdade, ser incorporadas por referência), - conjunto todo constitui um ramo separado de Direito, que fica fora do Direito das Obrigações, com seu sentido tradicional. Deve-se duvidar se tal conjunto de normas pode, com proveito, ser comparado com normas e princípios que tradicionalmente governam os acôrdos entre os indivíduos, os quais, são o resultado de ajustes no mercado livre. Por outro lado, poderia ser interessante e útil comparar o Direito Contratual referente aos atos jurídicos entre as emprêsas socialistas com instituições ocidentais, nas quais os elementos de liberdade e de ajuste são limitados ou inexistentes, tais como contratos resultantes do Kontrahierungszwang ou talvez com contratos governamentais em alguns países do Ocidente.

Finalmente, pode-se mencionar que o nôvo Código Civil da Tcheco-Eslováquia, de 26 de fevereiro de $1964\left({ }^{114}\right)$, que substituiu o Código de 1950, não seguiu os padrões contemporâneos, prevalecentes nos países comunistas. Conquanto tenha regulado relações dos particulares entre si e dêstes com unidades econômicas socialistas, omitiu-se quanto a todo o campo dos contratos econômicos concluídos na execução do plano econômico, separando-se do enfoque do Código de 1950. Assim, na Tcheco-Eslováquia, tais contratos não são mais considerados como parte do Direito Civil.

114. Vide Sb. n.o 19, item 40 (1964).

115. O Nôvo Código Civil Tcheco-Eslovaco tem sido descrito como "verdadeiramente revolucionário", porque "rejeita o Direito Civil Ocidental tradicional" e introduz "um nôvo espírito, uma nova aplicação do Direito"; comparado com êle o Código Polonês é "certamente não-revolucionário". RUDZINSKI, "Os Novos Códigos Civis Comunistas de Tcheco-Eslovaquia e Polônia: Uma Avaliação Geral", 41 Ind. L. J. 33 (1965) 